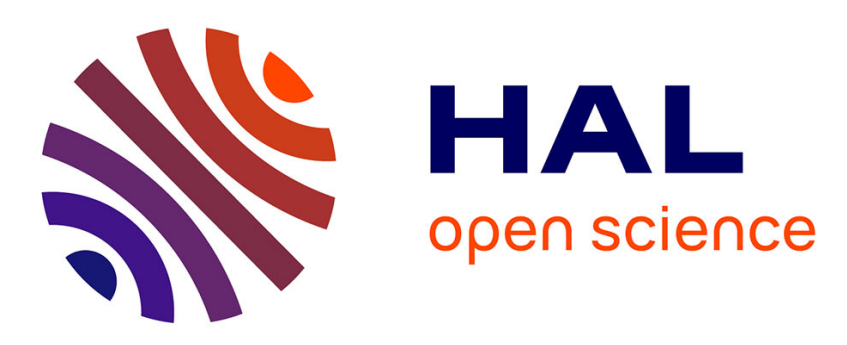

\title{
Removal of tiemonium methylsulfate, from aqueous solutions using activated carbon prepared from date stones
}

Fazia Agueniou, Derradji Chebli, Abdallah Bouguettoucha, Abdelbaki Reffas, Mohammed Lamine Sekirifa, Lotfi Baameur, Abdeltif Amrane

\section{To cite this version:}

Fazia Agueniou, Derradji Chebli, Abdallah Bouguettoucha, Abdelbaki Reffas, Mohammed Lamine Sekirifa, et al.. Removal of tiemonium methylsulfate, from aqueous solutions using activated carbon prepared from date stones. Particulate Science and Technology, 2019, 37 (2), pp.190-199. 10.1080/02726351.2017.1360972 . hal-01954263

\section{HAL Id: hal-01954263 \\ https://hal-univ-rennes1.archives-ouvertes.fr/hal-01954263}

Submitted on 24 Jan 2019

HAL is a multi-disciplinary open access archive for the deposit and dissemination of scientific research documents, whether they are published or not. The documents may come from teaching and research institutions in France or abroad, or from public or private research centers.
L'archive ouverte pluridisciplinaire HAL, est destinée au dépôt et à la diffusion de documents scientifiques de niveau recherche, publiés ou non, émanant des établissements d'enseignement et de recherche français ou étrangers, des laboratoires publics ou privés. 


\title{
Removal of Tiemoniummethylsulfate, from aqueous
}

\section{solutions using activated carbon prepared from date stones}

\author{
Fazia Agueniou
}

Département de Génie des Procédés, Laboratoire de Génie des Procédés Chimiques (LGPC), Faculté de Technologie, Université Ferhat Abbas, Sétif, Alégrie

\section{Derradji Chebli}

Département de Génie des Procédés, Laboratoire de Génie des Procédés Chimiques (LGPC), Faculté de Technologie, Université Ferhat Abbas, Sétif, Alégrie

\section{Abdallah Bouguettoucha}

Département de Génie des Procédés, Laboratoire de Génie des Procédés Chimiques (LGPC), Faculté de Technologie, Université Ferhat Abbas, Sétif, Alégrie

\author{
Abdelbaki Reffas
}

Département de Chimie, Laboratoire des Matériaux inorganiques (LMI), Faculté des Sciences, Université Mohamed BOUDIAF-M'sila, M'sila, Algérie

Mohammed Lamine sekirifa

Département de Chimie, Université de Ouragla

\section{Lotfi Baameur}

Département de Chimie, Université de Ouragla 


\begin{abstract}
Abdeltif Amrane
Ecole Nationale Supérieure de Chimie de Rennes, Université de Rennes 1, CNRS, UMR 6226, Rennes, France
\end{abstract}

\begin{abstract}
The retention of a pharmaceutical compound, Tiemoniummethylsulfate (TIM), from aqueous solutions by adsorption onto activated carbon prepared from date stones (AC-DS) was investigated. Physical and chemical characteristics of this material were also determined. Results showed that $\mathrm{pH} 8$ was optimal for TIM adsorption. Among the kinetic models considered, the pseudo-second order model was the most appropriate to describe experimental data. Regarding adsorption isotherms, it was shown that the Sips model accurately describe the sorption of TIM onto AC-DS with a correlation factor $\mathrm{R}^{2}>0.98$. The adsorption capacity of (AC-DS) was found to be $42.2 \mathrm{mg} \mathrm{g}^{-1}$ at $10^{\circ} \mathrm{C}$ and $60.5 \mathrm{mg} \mathrm{g}^{-1}$ at $25^{\circ} \mathrm{C}$, confirming its efficiency for the removal of this compound from aqueous solutions. The values of $\Delta \mathrm{G}^{0}$ and $\Delta \mathrm{H}^{0}$ confirmed that the adsorption of TIM onto AC-DS was spontaneous and endothermic in nature, and hence more effective at high temperatures. An irregular increase in the randomness was suggested at the AC-DS-solution interface during the adsorption process for positive values of $\Delta \mathrm{S}^{0}$.
\end{abstract}

KEYWORDS: activated carbon, adsorption, date stones, isotherm, kinetic, Tiemoniummethylsulfate

\title{
Introduction
}

The main water contaminants are generated by human and industrial activities. Note that almost all pharmaceutical products used for human or veterinary purpose are spread in nature and 
particularly in water (Barceló and Petrovic 2007; Diana and Aga 2008; Garcia-Galan, Silvia DiazCruz, and Barcelo 2008). The presence of pharmaceutical contaminant products in waters has pushed the scientific community to propose purification and decontamination techniques of these waters. Among the techniques available, the resistance and the recalcitrant nature of certain contaminants should be taken into account in the choice of the appropriate technique of treatment, which include flocculation, oxidation, adsorption, electrolysis, etc. (Ghaedi, Hassanzadeh, and NaciriKokhdan 2011; Wangpradit and Chitprasert 2014). Current research focuses on efficient methods to lower costs; thus, adsorption using activated carbon of vegetable origin appears to satisfy the scientific needs and completely fulfill the conditions requested for both efficiency and cost. Adsorption is an attractive technique owing to the high removal yields achieved, to its ease of implementation, since it does not require complex equipment and/or advanced technology, as well as to the plenty of adsorbents available in nature. However, adsorption is often implemented in complementary to other conventional purification methods, because adsorption is effective in the retention of soluble chemical compounds in water unmodified (Magriotis et al. 2014; Wang, Zhang, and Yao 2015), and hence a destructive post-treatment method is often needed. A wide range of adsorbents is used in water treatment, including activated carbon, biomass from agricultural waste, clays, polymeric resins, etc. (Hamzeh et al. 2012; Olushola et al. 2015). The use of natural adsorbent materials is a promising alternative due to their abundance and their relatively low price (Ramakrishnaiahand and Arpitha 2014; Jin et al. 2015). In this work, activated carbon based materials obtained from date stones were considered and used as a potential adsorbent for a pharmaceutical compound. Indeed, this class of adsorbents shows some interesting chemical and physical characteristics, such as a high developed porous structure, good thermal stability, low cost and accessibility. Date stones are among the most common agricultural by 
products available in palms growing in the Mediterranean countries like Algeria, which is one of the largest producers in the world. Date stones constitute more or less than $10 \%$ of the date weight. This lignocellulosic based agricultural waste is a very good precursor for preparing activated carbon owing to its excellent natural structure and low ash content (Bouchenafa-Saïb et al. 2005; Merzougui and Addoun 2008; Kim et al. 2015). As it is well known, two methods are commonly used for the preparation of activated carbon: physical and chemical activations. Compared with physical activation, the chemical activation presents some advantages like low activation temperature, short activation time, high surface area, well developed microporosity of the activated carbon, simple operation and low energy consumption (Deng et al. 2009; Pereira et al. 2014). For this purpose, date stones can be activated with chemical agents such as $\mathrm{KOH}, \mathrm{ZnCl}_{2}, \mathrm{H}_{3} \mathrm{PO}_{4}$, $\mathrm{K}_{2} \mathrm{CO}_{3}$ and $\mathrm{NaOH}$, to obtain activated carbons with well-developed textural characteristics. Therefore, the main objective of this work was to prepare activated carbon having high surfaces area from date stones by thermochemical activation with $\mathrm{CO}_{2}$. To our knowledge, no work has been reported in the literature regarding the removal of Tiemoniummethylsulfate from aqueous solutions by means of adsorption, neither onto activated carbon nor onto other adsorbents; it was therefore also examined in this study.

\section{Materials and Methods}

\section{Preparation of the adsorbent}

After separation of the cores of dates from their pulp, they were washed, placed in an oven at $130^{\circ} \mathrm{C}$ for 24 hours and then ground. The ground material fractions were then stored in tightly closed bottles for subsequent use as raw material of the activated carbon. The separation of fractions representative of the crushed sample was performed by a Fritsh type sifter. Pyrolysis of 
samples was carried out in a vertical furnace BGVA12-300b,Carbolite, United Kingdom) connected to the inlet and outlet devices; the system allowed to take into account the upward gas flow by the sample, as well as the evacuation and the trapping of exhaust gas and liquid condensates respectively. In this furnace, about $75 \mathrm{~g}$ of dates stones were placed in a cylindrical quartz cell (40mm diameter) comprising a sintered at half height disk. The different pyrolysis conditions considered are shown in Table 1.

\section{Adsorption study}

Adsorption of Tiemoniummethylsulfate (TIM) (Figure 1) from aqueous solutions was studied in batch mode. The effects of the mass of adsorbent, $\mathrm{pH}$, contact time and temperature were considered. After optimizing the operating parameters, kinetic, equilibrium and thermodynamic studies were conducted in $100 \mathrm{~mL}$ conical flasks containing $50 \mathrm{~mL}$ TIM solution of different initial concentrations in the range 5 to $50 \mathrm{mg} \mathrm{L}^{-1}$ for AC-DS under the optimal conditions. The flasks were agitated in a temperature controlled stirrer at 200rpm for a fixed time until equilibrium was established. After filtration of the samples taken from the flasks at the equilibrium adsorption time, the residual dye concentration was measured using an SP-8001 UV/VIS Spectrophotometer of Axiom, Germany (Shimadzu); it was measured at a wavelength of $234 \mathrm{~nm}$ with respect to a calibration curve prepared prior to the analysis. The thermodynamic study was carried out in $100 \mathrm{~mL}$ conical flasks containing $200 \mathrm{~mL}$ TIM solution of different initial concentrations in the range 50 to $200 \mathrm{mg} \mathrm{L}^{-1}$ and by varying the temperature from 10 to $40^{\circ} \mathrm{C}$. All sets of experiments were performed in duplicate under the optimal conditions and the mean values are given. 
The amount of Pharmaceutical adsorbed onto AC-DS at time t, Qt $\left(\mathrm{mg} \mathrm{g}^{-1}\right)$, was determined according to the following equation:

$$
\mathrm{Q}_{\mathrm{t}}=\frac{\left(\mathrm{C}_{0}-\mathrm{C}_{\mathrm{t}}\right) \mathrm{V}}{\mathrm{m}}
$$

Where $\mathrm{C}_{0}$ and $\mathrm{Ct}$ are respectively the initial concentration and the concentration of dye at a given time $\mathrm{t}\left(\mathrm{mg} \mathrm{L}^{-1}\right), \mathrm{m}$ is the mass of AC-DS and $\mathrm{V}$ is the volume of solution.

\section{Equilibrium modeling}

Usually equilibrium data are known as adsorption isotherms, describing how adsorbates interact with adsorbents and consequently are necessary in optimizing the use of adsorbents; they also provide information on the capacity of the adsorbent. To analyze AC-DS interaction with TIM, experimental data points were fitted to two-parameter isotherm models, namely Langmuir and Freundlich, and three-parameter isotherm models, namely Sips and Redlich-Peterson, which are the most frequently used in the literature to describe the non-linear equilibrium between the target molecules adsorbed on the adsorbent material (Qe) and the target molecules concentration (Ce) at equilibrium in solution and at a constant temperature.

\section{Two parameter isotherms}

In the Langmuir isotherm model, it is assumed that the energies of adsorption onto the adsorbent surface are uniform. In addition, the Langmuir equation support the assumption of the existence of identical sites on the outer surface of the adsorbent, and therefore only a single layer of pollutant covers the surface of the adsorbate. The Langmuir equation (Langmuir, 1918) is given as follows: 


$$
\frac{\mathrm{Q}_{\mathrm{e}}}{\mathrm{Q}_{\mathrm{m}}}=\frac{\mathrm{K}_{\mathrm{L}} \mathrm{C}_{\mathrm{e}}}{1+\mathrm{K}_{\mathrm{L}} \mathrm{C}_{\mathrm{e}}}
$$

Where Qe and Ce are the equilibrium dye concentration on the adsorbent $\left(\mathrm{mg} \cdot \mathrm{g}^{-1}\right)$ and the equilibrium dye concentration in solution respectively $\left(\mathrm{mg} \mathrm{L}^{-1}\right)$; $\mathrm{Qm}$ is the monolayer capacity of the adsorbent ( $\left.\mathrm{mg} \mathrm{g}^{-1}\right)$; and $\mathrm{K}_{\mathrm{L}}$ is the Langmuir constant. A non-linear fit was performed by using the Origin Software in order to obtain the Langmuir model parameters. The parameter statistic "adjusted R-square" were also determined to identify the most accurate model to describe the experimental results.

The Freundlich isotherm model (Freundlich, 1906) assumes neither homogeneous site energies nor limited levels of adsorption. The Freundlich model is a very old empirical equation, showing that it is compatible with an exponential distribution of the active sites of the adsorbent material; it is a characteristic of heterogeneous surfaces:

$$
\mathrm{Q}_{\mathrm{e}}=\mathrm{K}_{\mathrm{F}} \mathrm{C}_{\mathrm{e}}^{1 / \mathrm{n}}
$$

Where Qe is the equilibrium dye amount on the adsorbent $\left(\mathrm{mg} \mathrm{g}^{-1}\right)$; Ce is the equilibrium dye concentration in solution $\left(\mathrm{mg} \mathrm{L}^{-1}\right) ; \mathrm{K}_{\mathrm{F}}$ and $1 / n$ are empirical constants indicative of adsorption capacity and adsorption intensity, respectively. The Freundlich parameters were obtained by performing a non-linear fit (Origin software).

\section{Three parameter isotherms}

The Sips isotherm is a combination of the Langmuir and Freundlich isotherms (Sips 1948):

$$
\frac{\mathrm{Q}_{\mathrm{e}}}{\mathrm{Q}_{\mathrm{ms}}}=\frac{\left(\mathrm{Ks} \mathrm{C}_{\mathrm{e}}\right)^{\mathrm{m}}}{1+\left(\mathrm{KsC}_{\mathrm{e}}\right)^{\mathrm{m}}}
$$


Where $\mathrm{Q}_{\mathrm{mS}}$ is the maximum monolayer adsorption $\left(\mathrm{mg} \mathrm{g}^{-1}\right)$, Ks is the Sips constant solution $\left(\mathrm{mg} \mathrm{L}^{-1}\right)$ and $\mathrm{m}$ the exponent of the Sips model.

The Redlich-Peterson isotherm model (R-P) (Prasad and Srivastava 2009) is a hybrid isotherm that approaches the Freundlich model at high concentrations(g tends to zero) and the Langmuir model at low concentrations ( $\mathrm{g}$ tends to one); this isotherm is therefore often used as a compromise between the Freundlich the and Langmuir models. The $\mathrm{R}-\mathrm{P}$ isotherm equation is expressed by the following equation:

$$
\mathrm{Q}_{\mathrm{e}}=\frac{\mathrm{K}_{\mathrm{R}} \cdot \mathrm{C}_{\mathrm{e}}}{1+\mathrm{a}_{\mathrm{R}} \cdot \mathrm{C}_{\mathrm{e}}^{\mathrm{g}}}
$$

where $\mathrm{K}_{\mathrm{R}}$ and $\mathrm{a}_{\mathrm{R}}$ are the $\mathrm{R}-\mathrm{P}$ constants $\left(\mathrm{L} \mathrm{g}^{-1}\right)$; the ratio of $\mathrm{K}_{\mathrm{R}} / \mathrm{a}_{\mathrm{R}}$ indicates the adsorption capacity is an exponent which lies between 0 and $1, \mathrm{Ce}$ is the equilibrium concentration of the adsorbate $\left(\mathrm{mg} \mathrm{L}^{-1}\right)$ and Qe is the equilibrium adsorbate onto the adsorbent $\left(\mathrm{mg} \mathrm{g}^{-1}\right)$.

In addition, three different error functions were employed in order to find the most appropriate isotherm to describe experimental data. Relationships for error analysis, namely, chisquare test $\left(\chi^{2}\right)$, hybrid fractional error function (HYBRID) and average relative error (ARE) are represented as follows:

$$
\begin{gathered}
\chi^{2}=\sum_{\mathrm{i}=1}^{\mathrm{n}} \frac{\left(\mathrm{Q}_{\mathrm{e}, \mathrm{exp}}-\mathrm{Q}_{\mathrm{e}, \mathrm{cal}}\right)^{2}}{\mathrm{Q}_{\mathrm{e}, \mathrm{exp}}} \\
\mathrm{HYBRID}=\frac{100}{\mathrm{n}-\mathrm{p}} \sum_{\mathrm{i}=1}^{\mathrm{n}}\left[\frac{\left(\mathrm{Q}_{\mathrm{e}, \mathrm{exp}}-\mathrm{Q}_{\mathrm{e}, \mathrm{aal}}\right)^{2}}{\mathrm{Q}_{\mathrm{e}, \mathrm{exp}}}\right]_{\mathrm{i}} \\
\mathrm{A} R E=\frac{100}{\mathrm{n}} \sum_{\mathrm{i}=1}^{\mathrm{n}}\left[\frac{\left(\mathrm{Q}_{\mathrm{e}, \mathrm{exp}}-\mathrm{Q}_{\mathrm{e}, \mathrm{cal}}\right)^{2}}{\mathrm{Q}_{e, \mathrm{exp}}}\right]_{\mathrm{i}}
\end{gathered}
$$


Where $\mathrm{Q}_{\mathrm{e}, \exp }$ is the experimental value, $\mathrm{Q}_{\mathrm{e}, \text { calc }}$ is the calculated value, $\mathrm{n}$ is the number of data points in the considered experiment, and $\mathrm{p}$ is the number of parameters of the model.

\section{Kinetic modeling}

The study of adsorption dynamics describes the solute adsorption rate on the adsorbent; this rate controls the residence time of adsorption at the solid-solution interface. Among the numerous models available to describe adsorption kinetics, pseudo-first-order, pseudo-secondorder and Elovich models were applied to fit experimental data.

\section{Pseudo-first-order model}

The pseudo-first-order kinetic model based on the adsorption capacity is the first equation for the adsorption of solid/liquid system. The linear form of the pseudo-first-order equation (Lagergren 1898) is given by Eq. (9):

$$
\ln \left(\mathrm{Q}_{\mathrm{e}}-\mathrm{Q}_{\mathrm{t}}\right)=\ln \mathrm{Q}_{\mathrm{e}}-\mathrm{k}_{1} \mathrm{t}
$$

Where Qe $\left(\mathrm{mg} \mathrm{g}^{-1}\right)$ and Qt $\left(\mathrm{mg} \mathrm{g}^{-1}\right)$ are the amount of dye adsorbed at equilibrium and at time $\mathrm{t}(\mathrm{min})$, respectively; $\mathrm{k}^{1}\left(\mathrm{~min}^{-1}\right)$ is the equilibrium rate constant of pseudo-first-order equation. The rate constants are obtained from the straight line plots of $\ln (\mathrm{Qe}-\mathrm{Qt})$ versus $\mathrm{t}$.

\section{Pseudo-second-order model}

The pseudo-second-order model is based on the assumption of chemisorption of the adsorbate on the adsorbent (Srivastava, Mall, and Mishra 2008). This model is given by Eq. (10):

$$
\frac{\mathrm{t}}{\mathrm{Q}_{\mathrm{t}}}=\frac{1}{\mathrm{k}_{2} \mathrm{Q}_{\mathrm{e}}^{2}}+\frac{1}{\mathrm{Q}_{\mathrm{e}}} \mathrm{t}
$$


Where $\left.\mathrm{k}_{2}\left(\mathrm{~g} \mathrm{mg}^{-1} \mathrm{~min}^{-1}\right)\right)$ is the equilibrium rate constant of pseudo-second-order equation. The straight line plot of $\mathrm{t} / \mathrm{Qt}$ against $\mathrm{t}$ allows to obtain the rate constants.

\section{Elovich model}

The Elovich model (Önal 2006) results in the linear equation (11).

$$
\mathrm{Q}_{\mathrm{t}}=\frac{1}{\beta} \ln (\alpha \cdot \beta)+\frac{1}{\beta} \ln (\mathrm{t})
$$

Where $\alpha$ is the initial adsorption rate constant $\left(\mathrm{mg}\left(\mathrm{g}^{-1} \mathrm{~min}^{-1}\right)\right)$ and the $\beta$ is related to the activation energy for chemisorption and also to the extent of surface coverage $\left(\mathrm{g} \mathrm{mg}^{-1}\right)$. The values of $\alpha$ and $\beta$ can be derived from plotting Qt as a function of $\ln (\mathrm{t})$.

\section{Intraparticle diffusion model}

Intraparticle diffusion model is commonly used to identify the adsorption mechanism for design purpose. According to Weber and Morris (1963), for most adsorption processes, the uptake varies almost proportionately with $\mathrm{t}^{1} / 2$ rather than with the contact time and can be represented as follows:

$$
\mathrm{Qt}=\mathrm{k}_{\mathrm{id}}{ }^{0.5} \mathrm{t}+\mathrm{C}
$$

Where Qt is the amount adsorbed at time $\mathrm{t}$ and $\mathrm{t}^{0.5}$ is the square root of the time, $\mathrm{C}$ is the intercept, and kid ( $\left.\mathrm{mg} \mathrm{g}^{-1} \mathrm{~min}^{-0.5}\right)$ is the rate constant of intraparticle diffusion.

\section{Results and Discussion}

\section{Characterization}




\section{Elemental analysis}

Table 2 shows that AC-DS contained mainly carbon (87.41\%) and oxygen (8.40\%), with few amount of nitrogen $(2.40 \%)$, hydrogen $(0.99 \%)$ and sulfur $(<0.10 \%)$. As the activation of native date stones, N-DS, the carbon content increased with the activation, from $50.51 \%$ to $88.77 \%$ and $87.41 \%$ after calcination and chemical activation, respectively; whereas the oxygen content decreased from $38.81 \%$ for N-DS to $8.40 \%$ for AC-DS. The content of hydrogen and sulfur also decreased with the activation. Since AC-DS (Table 2) contained a higher amount of carbon and a lower content of heteroatoms ( $8.40 \%$ of $\mathrm{O}$ for instance) if compared to N-DS, its surface was less acidic.

\section{Nitrogen sorption}

The $\mathrm{N}_{2}$ adsorption-desorption isotherm of the activated carbons (AC-DS) is shown in Figure 2. The isotherm for AC-DS was typical of microporous materials where the micropore filling takes place in the wider micropores (type $\mathrm{Ib}$ ) over a range of high pressures $\mathrm{P} / \mathrm{P}_{0}$ (Rouquerol, Rouquerol, and Sing 1999). Nevertheless, for AC-DS, a plateau was not clearly reached, indicating a widening of pores. The isotherm exhibited a type H4 hysteresis loop, characteristic of slit-shaped pores. Finally, the AC-DS isotherm showed an important adsorption at low $\mathrm{P} / \mathrm{P}_{0}$ and a type $\mathrm{H} 4$ hysteresis loop, corresponding to the simultaneous presence of micropores and mesopores. The less pronounced hysteresis loop for AC-DS indicated that its mesoporous volume was the smallest if compared to the native date stones (N-DS). The BET surface area of C-DS and AC-DS, were 865.59 and $1295.20 \mathrm{~m}^{2} \mathrm{~g}^{-1}$ respectively (Table 3), which can be favorably compared with other activated carbons produced from vegetal materials (Nakamura et al. 2003; Namane et al. 2005; Reffas et al. 2010). Contrarily to the SBET, the diameter of pores was lower for AC-DS, $1.39 \mathrm{~nm}$ 
if compared to C-DS, $2.62 \mathrm{~nm}$. The C-DS was microporous and mesoporous according to the values of the total pore volume, measured by the BJH and the BET methods (Table 3). Table 4 illustrates the textural parameters according to the Dubinin-Radushkevich (D-R) model, showing that AC-DS mainly exhibited pores of diameter lower than $2 \mathrm{~nm}$; while C-DS presented a distribution shifting towards larger pore sizes ( $>2 \mathrm{~nm}$ ), as confirmed by the BJH value of C-DS (Table 3). Owing to its high mesopore content, C-DS might be an excellent adsorbent for organic pollutants of middle molecular size (>2 nm).

$p H_{P Z C}$ and surface functional groups

The $\mathrm{pH}$ PZC as well as the oxygenated group contents obtained by titrations are reported in

Table 5. The pHPZC value of AC-DS was 7.7 (Figure 3), namely rather an alkaline carbon in agreement with its low oxygen content. The rather alkaline value of the pHPZC for AC-DS (7.7) compared to other GACs (prepared for instance from vegetal material, $\mathrm{pH}$ PZC $<3.7$ (Reffas et al. 2010) can be attributed to the conditions of pyrolysis (Table 1), namely the increase of the time and temperature of calcination under inert gas flow, resulting in a decrease of the oxygen content at the surface (Tables 1 and 5). The "Boehm" titration of AC-DS (Table 5) showed less basic than acidic groups, which did not confirm its alkaline character. Thus, the $\mathrm{pH}$ PZC of AC-DS can be attributed to the presence of oxygenated surface groups with high pKa values.

\section{Infrared Spectroscopy}

Generally, the IR spectrum of activated carbon comprises stretching vibration and deformation bands of the $\mathrm{OH}, \mathrm{C}-\mathrm{H}, \mathrm{C} \equiv \mathrm{O}, \mathrm{C}=\mathrm{O}, \mathrm{C}=\mathrm{C}$ and $\mathrm{C}-\mathrm{O}$ functions, belonging to the phenolic, lactones and carboxylic acids groups. Figure 4 shows an intense and broad band between 3300 and $3600 \mathrm{~cm}^{-1}$ with a maximum at about $3445 \mathrm{~cm}^{-1}$ corresponding to the stretching vibrations of 
the hydroxyl groups $\mathrm{OH}$ (hydroxy, phenolic or alcohols groups) and physisorbed water. The band at $2920 \mathrm{~cm}^{-1}$ characterized the stretching vibrations of $\mathrm{C}-\mathrm{H}$; that at $1630 \mathrm{~cm}^{-1}$ can be assigned to $\mathrm{C}=\mathrm{C}$ band vibrations of the benzene ring. The band at $650 \mathrm{~cm}^{-1}$ can be assigned to the deformation vibration of $\mathrm{C}-\mathrm{H}$ bonds. It should be noted that the same bands as those before adsorption were observed after adsorption. The weak band at $3100 \mathrm{~cm}^{-1}$ corresponded to the $\mathrm{N}-\mathrm{H}$ bond and the bands at $3020 \mathrm{~cm}^{-1}$ and $1450 \mathrm{~cm}^{-1}$ corresponded to the $\mathrm{C}-\mathrm{H}$ and $\mathrm{C}=\mathrm{C}$ bonds, respectively. Bands between 1000 and $1250 \mathrm{~cm}^{-1}$ were characteristic of $\mathrm{C}-\mathrm{C}$ bonds, and those at 750 and $600 \mathrm{~cm}^{-1}$ were characteristic of $\mathrm{C}-\mathrm{H}$ bonds.

\section{Scanning electron microscopy}

Scanning electron microscopy (SEM) of C-DS and AC-DS absorbent before adsorption were visualized by using Hitachi tabletop Microscope TM-1000. The SEM analyzes were measured without EDS because the contents of C, H, N, O and S (w\%) of C-DS and AC-DS were measured by elemental analysis. The scanning electron microscopy image (obtained by diffusion of the secondary electrons at a scale of approximately $100 \mu \mathrm{m}$ ) of C-DS prepared from a lignocellulosic material (N-DS) shows a more smooth surface morphology (Figure 5a). In addition, the SEM image of AC-DS shows some supermicropores and cracks (diameter in the range of $1.39 \mathrm{~nm}$ ). The surface of the activated carbon (AC-DS) observed by SEM (Figure 5b) displays few microspores and a relatively heterogeneous surface morphology.

\section{Effect of the adsorption parameters}

\section{Effect of $p H$}


Adsorption of Tiemoniummethylsulfate (TIM) cation is favorable at $\mathrm{pH}>\mathrm{pHpzc}$ due to electrostatic interactions. In aqueous solution, Tiemoniummethylsulfate is dissociated and converted to cationic ion whatever the $\mathrm{pH}$ of the solution. This means that the adsorption of TIM on the activated carbon is only dependent on the charge of the activated carbon surface. The data presented in Figure 6 indicate change of adsorption with the $\mathrm{pH}$. The evolution of the adsorption in the investigated range of $\mathrm{pH}$ shows that the adsorption was optimal at $\mathrm{pH} 8$, namely slightly above the point of zero charge $(\mathrm{pHpzc}=7.7)$. Adsorption can be envisaged by an electrostatic interaction between the positive groups of Tiemoniummethylsulfate and the negative charge of activated carbon. This interaction decreased with decreasing $\mathrm{pH}$, due to an electrostatic repulsion between the TIM molecule (positive) and the negatively charge of the activated carbon surface when the $\mathrm{pH}$ was below $\mathrm{pHpzc}=7.7$.

\section{Effect of the contact time and the initial concentration}

The results obtained in this study are shown in Figure 7. It can be seen that irrespective of its initial concentration, the TIM removal was very fast during the first few minutes of adsorption, which can be explained by the availability of active sites on the surface of the adsorbent. Then, decreasing rates can be observed until reaching equilibrium after the occupation of the majority of the active sites by TIM ions, in accordance with the related literature (Shukla et al. 2002). It was also observed that an increase of the initial TIM concentration led to an increase in the adsorption of TIM by AC-DS. The maximum adsorption of TIM at equilibrium increased from 15 to $35 \mathrm{mg} \mathrm{g}^{-1}$ for increasing concentrations from 5 to $20 \mathrm{mg} \mathrm{L}^{-1}$; while no further increase of the amount adsorbed was observed beyond this concentration. It is also shown in Figure 5 that about $120 \mathrm{~min}$ were needed to reach equilibrium for 5 and $10 \mathrm{mg} \mathrm{L}^{-1}$ initial TIM concentrations; while for higher initial concentrations, 250min were necessary to achieve equilibrium. 


\section{Isotherm analysis}

In Figure 8, the fitted experimental data obtained at different temperatures showed that the temperature has a positive effect on the adsorption capacity of TIM. Qe values were 42.2, 50.6, 56.4 and $60.5 \mathrm{mg} \mathrm{g}^{-1}$ for $10,25,35$ and $40{ }^{\circ} \mathrm{C}$, respectively.

An increase in temperature improved therefore TIM absorption on the material, showing an impact of the thermodynamic phenomena on the process. The isotherm parameters obtained experimentally for all temperatures are shown in Table 6. The constants isotherms models, namely, statistical tests $x^{2}$, average relative errors (ARE), hybrid and $\left(\mathrm{R}^{2}\right)$ based on the difference between the values predicted by the models and the experimental points are also given. All the $\mathrm{R}^{2}$ values were lower than 0.97 , indicating an accurate fit for both two and three parameters models; with however slightly lower $\mathrm{R}^{2}$ values for the two-parameter isotherms. Based on the $\mathrm{R}^{2}$ and low $X^{2}$ values, the models can be classified as follows: Sips > Redlich Peterson > Langmuir > Freundlich. The superiority of the three-parameter isotherms over the two-parameter ones was in agreement with the related literature (Gunay, Arslankaya, and Tosun 2007). The Sips isotherm model gave the highest $\mathrm{R}^{2}$ value and the most accurate estimation of the maximum adsorption capacity $(\mathrm{Qm})$ compared to the experimental value. However, the adsorption capacity Qm obtained from the Langmuir equation appeared more realistic than that obtained from the Sips equation compared to the experimental values, $Q_{\exp }$ (Table 6). Statistical values (ARE) confirmed that the Sips model was the most relevant to describe experimental data (Table 7).

\section{Kinetics analysis}

According to Canzano et al. (2007) the data at or near the equilibrium could be omitted because high $t$ values lead to extremely high errors. For the AC-DS adsorbent, it may be noted that 
except for $5 \mathrm{mg} \mathrm{L}^{-1} \mathrm{TIM}$, adsorption kinetics appeared to be more accurately fitted by the pseudosecond-order model (Figure 9b, Table 8), compared to the pseudo-first-order model (Figure 9a, Table 10). Similar tendencies were found by Larous and Meniai (2016) for the removal of Diclofenac onto olive stones. Regarding the Elovich model, it did not result in an accurate description of experimental data, owing to the low correlation coefficients $\left(\mathrm{R}^{2}\right)$ observed for 5 and 50mg L L TIM (Figure 10 and Table 8). Furthermore, the Qe values estimated from the pseudosecond-order kinetic and pseudo-first-order models were also in agreement with experimental data for all tested concentrations (Table 8).

The intraparticle diffusion model could be used to investigate the mass transfer mechanism in the TIM- activated carbon system. The intercept gives an idea about the thickness of the boundary layer, i.e. the larger is the intercept the greater is the boundary layer effect (Özer, Akkaya, and Turabik 2006). The intraparticle diffusion plots are displayed in Figure 11 and the parameters are summarized in Table 9. This figure showed that irrespective of the considered concentartion, the intraparticle diffusion of TIM within activated carbon occurred in two steps. The first straight portion could be attributed to macropore diffusion (step 1), namely the transport of TIM molecules from the bulk solution to the surface of the adsorbent, and the second linear portion could be attributed to micropore diffusion (step 2), namely the binding of the TIM molecules on the active sites of adsorption. Intraparticle diffusion appeared therefore to be the limiting step for the adsorption of TIM onto AC-DS adsorbent.

\section{Thermodynamic analysis}

The thermodynamic parameters reflect the spontaneous nature and the feasibility of a sorption process. Parameters such as the free energy change $(\Delta \mathrm{G})$, the enthalpy change $(\Delta \mathrm{H})$ and 
the entropy change $(\Delta S)$ can be estimated from equilibrium constants varying with temperature. The free energy variation of the adsorption reaction is illustrated by Eq. (12) as reported by Milonjic (2007):

$$
\Delta \mathrm{G}^{\circ}=-\mathrm{RT} \ln (\rho \mathrm{Kc})
$$

Where $\Delta \mathrm{G}^{0}$ is the free energy change $\left(\mathrm{kJ} \cdot \mathrm{mol}^{-1}\right), \mathrm{R}$ the universal gas constant $\left(8.31 \mathrm{~J} . \mathrm{mol}^{-1} \mathrm{~K}^{-1}\right), \mathrm{T}$ the absolute temperature $(\mathrm{K}), \mathrm{KC}$ the thermodynamic equilibrium constant $(\mathrm{L}$ $\left.\mathrm{g}^{-1}\right)\left(\right.$ Eq. 14) and $\rho$ the water density $\left(\mathrm{g} \mathrm{L}^{-1}\right) \cdot \Delta \mathrm{H}^{0}$ and $\Delta \mathrm{S}^{0}$ values of the adsorption process were calculated from the Van't Hoff equation (13):

$$
\begin{gathered}
\ln \left(\rho \mathrm{K}_{\mathrm{C}}\right)=-\frac{\Delta \mathrm{H}^{\mathrm{o}}}{\mathrm{RT}}+\frac{\Delta \mathrm{S}^{\mathrm{o}}}{\mathrm{R}} \\
\mathrm{K}_{\mathrm{C}}=\frac{\mathrm{Q}_{\mathrm{e}}}{\mathrm{C}_{\mathrm{e}}}
\end{gathered}
$$

$\Delta H^{0}$ and $\Delta S^{0}$ can be then determined from the slope $\left(\Delta H^{0} / R\right)$ and the intercept $\left(\Delta S^{0} / R\right)$ of the plot of $\ln (\rho \mathrm{KC})$ versus $1 / \mathrm{T}$. The obtained thermodynamic parameters are collected in Table 10. The change in free energy for physisorption is between -20 and $0 \mathrm{~kJ} / \mathrm{mol}$ and in a range of 80 to $-400 \mathrm{~kJ} / \mathrm{mol}$ for chemisorptions (Chiou and Li 2003). The results obtained were slightly below $-20 \mathrm{~kJ} / \mathrm{mol}$ for AC-DS at all tested temperatures, namely characteristics of a spontaneous physisorption process; it was in agreement with the low impact of the temperature on TIM adsorption. The values of $\Delta \mathrm{H}^{0}$ confirmed that the adsorption of TIM onto AC-DS was endothermic in nature. A random increase at the solid-solution interface during adsorption of the TIM on AC-DS was probably linked to the positive change of entropy.

\section{Conclusion}


In this study, Date stones wastes have been considered to prepare activated carbon by a classical method and Tiemoniummethylsulfate was used as a model compound. It was observed that activation of the adsorbent material with carbon dioxide promotes the increase of the surface.

Experimental data were found to follow a Langmuir model in the case of two parameter isotherms and the Sips isotherm model in the case of three parameter isotherms. Batch studies showed that a simple model such as a pseudo-second-order kinetic equation can adequately predict the adsorption of TIM onto AC-DS at all studied concentrations. These results imply that physisorption mechanism may play an important role in dye adsorption.

This study demonstrated therefore that AC-DS showed to be a promising adsorbent, owing to its efficiency for the removal of a pharmaceutical product, Tiemoniummethylsulfate, from wastewater.

\section{Acknowledgments}

The authors would like to thank the Salem laboratory group for the provision of the Tiemoniummethylsulfate.

\section{References}

Barceló, D., and M. Petrovic. 2007. Analysis, fate and removal of pharmaceuticals in the water cycle. Comprehensive analytical chemistry 50:4-6.

Bouchenafa-Saïb, N., P. Grange, P. Verhasselt, F. Addoun, and V. Dubois. 2005. Effect of oxidant treatment of date pit active carbons used as Pd supports in catalytic hydrogenation of nitrobenzene. Applied Catalalysis A: General 286 (2):167-74. doi:10.1016/j.apcata.2005.02.022.

Canzano, S., P. Iovino, V. Leone, S. Salvestrini, and S. Capasso. 2012. Use and misuse of sorption kinetic data: A common mistake that should be avoided. Adsorption Science and Technology 30:217-26. doi:10.1260/0263-6174.30.3.217. 
Chiou, M. S., and H. Y. Li. 2003. Adsorption behavior of reactive dye in aqueous solution on chemical cross-linked chitosan beads. Chemosphere 50:1095-105. doi:10.1016/s00456535(02)00636-7.

Deng, H., L. Yang, G. Tao, and J. Dai. 2009. Preparation and characterization of activated carbon from cotton stalk by microwave assisted chemical activation-Application in methylene blue adsorption from aqueous solution. Journal of Hazardous Materials 166 (2-3):1514-21. doi:10.1016/j.jhazmat.2008.12.080.

Diana, S., and I. Aga. 2008. Fate of pharmaceuticals in the environment and in water treatment systems, 35-38. Boca Raton, FL: CRC Press.

Freundlich, H. M. F. 1906. Ober dies adsorption in Losungen (About adsorption in solution). Zeitschrift für Physikalische Chemie 57:385-470.

Garcia-Galan, M. J., M. Silvia Diaz-Cruz, and D. Barcelo. 2008. Identification and determination of metabolites and degradation products of sulfonamide antibiotics. Trac-Trends in Analytical Chemistry 27:1008-22. doi:10.1016/j.trac.2008.10.001.

Ghaedi, M., A. Hassanzadeh, and S. NaciriKokhdan. 2011. Multiwalled carbon nanotubes as adsorbents for the kinetic and equilibrium study of the removal of alizarin red $\mathrm{S}$ and morin. Journal of Chemical and Engineering Data 56:2511-20. doi:10.1021/je2000414.

Gunay, A., E. Arslankaya, and I. Tosun. 2007. Lead removal from aqueous solution by natural and pretreated clinoptilolite: Adsorption equilibrium and kinetics. Journal of Hazardous Materials 146:362-71. doi:10.1016/j.jhazmat.2006.12.034.

Hamzeh, Y., A. Ashori, E. Azadeh, and A. Abdulkhan. 2012. Removal of Acid Orange 7 and Remazol Black 5 reactive dyes from aqueous solutions using a novel biosorbent. Journal of Materials Science and Engineering 32:394-1400. doi:10.1016/j.msec.2012.04.015.

Jin, L., Q. Sun, Q. Xu, and Y. Xu. 2015. Adsorptive removal of anionic dyes from aqueous solutions using microgel based on nanocellulose and polyvinylamine. Bioresource Technology 197:348-55. doi:10.1016/j.biortech.2015.08.093.

Kim, S. Y., M. R. Jin, C. H. Chung, Y. S. Yun, K. Y. Jahng, and K. Y. Yu. 2015. Biosorption of cationic basic dye and cadmium by the novel biosorbent Bacillus catenulatus JB-022 strain. Journal of Bioscience and Bioengineering 119 (4):433-39. doi:10.1016/j.jbiosc.2014.09.022.

Lagergren, S. 1898. ZurTheorie der sogenannten Adsorption gelösterStoffe (On the theory of socalled adsorption of solutes). Kungliga svenska vetenskapsakademiens. Handlingar 24:1-39.

Langmuir, I. 1918. The adsorption of gases on plane surfaces of glass, mica and platinum. Journal of the American Chemical Society 40:1361-1403. doi:10.1021/ja02242a004.

Larous, S., and A. H. Meniai. 2016. Adsorption of Diclofenac from aqueous solution using activated carbon prepared from olive stones. International Journal of Hydrogen Energy 41 (24):10380-90. doi:10.1016/j.ijhydene.2016.01.096.

Magriotis, Z. M., M. Z. Carvalho, P. F. de Sales, F. C. Alves, R. F. Resende, and A. A. Saczk. 2014. Castor bean (Ricinuscommunis L.) press cake from biodiesel production: An efficient low 
cost adsorbent for removal of textile dyes. Journal of Environmental Chemical Engineering 2:1731-40. doi:10.1016/j.jece.2014.07.005.

Merzougui, Z., and F. Addoun. 2008. Effect of oxidant treatment of date pit activated carbons application to the treatment of waters. Desalination 222 (1-3):394-403. doi:10.1016/j.desal.2007.01.134.

Milonjic, S. K. 2007. A consideration of the correct calculation of thermodynamic parameters of adsorption. Journal of Serbian Chemical Society 72:1363-67. doi:10.2298/jsc0712363m.

Nakamura, T., T. Tokimoro, N. Kawasaki, and S. Tanada. 2003. Decolorization of acidic dye by charcoal from coffee grounds. Journal of Health Science 49:520-23. doi:10.1248/jhs.49.520.

Namane, A., A. Mekarzia, K. Benrachedi, N. Belhaneche-Bensemra, and A. Hellal. 2005. Determination of the adsorption capacity of activated carbon made from coffee grounds by chemical activation with $\mathrm{ZnCl}_{2}$ and $\mathrm{H}_{3} \mathrm{PO}_{4}$. Journal of Hazardous Materials B 119:189-94. doi:10.1016/j.jhazmat.2004.12.006.

Olushola, S., S. Ayanda Olalekan, A. Fatoki, Folahan J. Adekola, B. Ximba, and L. F. Petrik. 2015. Kinetics, isotherm and thermodynamics of tributyltin removal by adsorption onto activated carbon, silica and composite material of silica and activated carbon. Desalination Water Treatment 53 (5):1361-70.

Önal, Y. 2006. Kinetics of adsorption of dyes from aqueous solution using activated carbon prepared from waste apricot. Journal of Hazardous Materials 137:1719-28. doi:10.1016/j.jhazmat.2006.05.036.

Özer, A., G. Akkaya, and M. Turabik. 2006. Biosorption of Acid blue 290 (AB 290) and Acid blue 324 (AB 324) dyes on Spirogyra rhizopus. Journal of Hazardous Materials 135:355-64. doi:10.1016/j.jhazmat.2005.11.080.

Pereira, R. G., C. M. Veloso, N. M. da Silva, L. F. de Sousa, R. C. F. Bonomo, and A. O. de Souza. 2014. Preparation of activated carbons from cocoa shells and siriguela seeds using $\mathrm{H}_{3} \mathrm{PO}_{4}$ and $\mathrm{ZnCl}_{2}$ as activating agents for BSA and $\alpha$-lactalbumin adsorption. Fuel Processing Technology 126:476-86. doi:10.1016/j.fuproc.2014.06.001.

Prasad, R. K., and S. N. Srivastava. 2009. Sorption of distillery spent wash onto fly ash: Kinetics and mass transfer studies. Chemical Engineering Journal 146 (1):90-97. doi:10.1016/j.cej.2008.05.021.

Ramakrishnaiahand, C. R., and D. N. Arpitha. 2014. Removal of colour from textile effluent by adsorption using low cost adsorbents. International Research Journal of Pure and Applied Chemistry 4 (5):568-77.

Reffas, A., V. Bernardet, B. David, L. Reinert, M. Dubois, M. B. Lehocine, and L. Duclaux. 2010. Carbons prepared from coffee grounds by $\mathrm{H}_{3} \mathrm{PO}_{4}$ activation: Characterization and adsorption of methylene blue and Nylosan Red N-2RBL. Journal of Hazardous Materials 175:779-88. doi:10.1016/j.jhazmat.2009.10.076.

Rouquerol, F., J. Rouquerol, and K. Sing. 1999. Adsorption by powders and porous solids: Principles, methodology and applications. London: Academic Press. 
Shukla, A., Y. H. Zhang, P. Dubey, J. L. Margrave, and S. S. Shukla. 2002. The role of sawdust in the removal of unwanted materials from water. Journal of Hazardous Materials B 95:137-52. doi:10.1016/s0304-3894(02)00089-4.

Sips, R. 1948. On the structure of a catalyst surface. Journal of Chemical Physics 16:490-95. doi: $10.1063 / 1.1746922$.

Srivastava, V. C., I. D. Mall, and I. M. Mishra. 2008. Adsorption of toxic metal ions onto activated carbon study of sorption behavior through characterization and kinetics. Chemical Engineering and Processing 47:1269-80. doi:10.1016/j.cep.2007.04.006.

Wang, M. X., Q. L. Zhang, and S. J. Yao. 2015. A novel biosorbent formed of marine-derived Penicillium janthinellum mycelial pellets for removing dyes from dye-containing wastewater. Chemical Engineering Journal 259:837-44. doi:10.1016/j.cej.2014.08.003.

Wangpradit, R., and P. Chitprasert. 2014. Chitosan-coated Lentinuspolychrous Lev: Integrated biosorption and biodegradation systems for decolorization of anionic reactive dyes. International Biodeterioration and Biodegradations 93:168-76. doi:10.1016/j.ibiod.2014.05.018.

Weber, W. J., and J. C. Morris. 1963. Equilibrium and capacities for adsorption on carbon. Journal of the Sanitary Engineering Division 89:31-60. 
Table 1. Conditions of pyrolysis of native date stones (N-DS).

\begin{tabular}{|c|c|c|c|c|c|}
\hline Sample & Furnace type & $\begin{array}{c}\text { Calcination } \\
\text { température } \\
\left({ }^{\circ} \mathrm{C}\right)\end{array}$ & $\begin{array}{c}\text { Duration of } \\
\text { calcination } \\
(\min )\end{array}$ & $\begin{array}{c}\text { Flow of } \mathrm{N}_{2} \\
(\mathrm{ml} / \mathrm{min})\end{array}$ & $\begin{array}{c}\text { Ramp } \\
\left({ }^{\circ} \mathrm{C} / \mathrm{min}\right)\end{array}$ \\
\hline N-DS & Vertical & 700 & 120 & 250 & 15 \\
\hline
\end{tabular}


Table 2. Elemental analysis of dates stones, native (N-DS), calcined (C-DS) and activated respectively (AC-DS).

\begin{tabular}{|c|c|c|c|c|c|}
\hline Sample & $\mathrm{C}(\%)$ & $\mathrm{H}(\%)$ & $\mathrm{N}(\%)$ & $\mathrm{O}(\%)$ & $\mathrm{S}(\%)$ \\
\hline N-DS & 50.51 & 6.99 & 1.34 & 38.81 & 0.12 \\
\hline C-DS & 88.77 & 1.01 & 2.45 & 6.09 & $<0.10$ \\
\hline AC-DS & 87.41 & 0.99 & 2.40 & 8.40 & $<0.10$ \\
\hline
\end{tabular}


Table 3. Textural characteristics calculated from the $\mathrm{N}_{2}$ adsorption isotherms at $77.35 \mathrm{~K}$ for the considered sample.

\begin{tabular}{|c|c|c|c|c|c|c|c|c|c|}
\hline Calcin & \multicolumn{3}{|c|}{ Specific area $\left(\mathrm{m}^{2} / \mathrm{g}\right)$} & \multicolumn{3}{|c|}{ Pore diameter $(\mathrm{nm})$} & \multicolumn{3}{|c|}{ Total pore volume $\left(\mathrm{cm}^{3} / \mathrm{g}\right)$} \\
\hline ed & By & $\mathrm{BJH}$ & $\mathrm{BJH}$ & By & $\mathrm{BJH}$ & $\mathrm{BJH}$ & By & $\mathrm{BJH}$ & $\mathrm{BJH}$ \\
\hline precur & the & cumulat & cumulat & the & adsorpti & desorpti & the & adsorpti & desorpti \\
\hline \multirow[t]{3}{*}{ sor } & BET & ive & ive & BET & on & on & BET & & on \\
\hline & meth & adsorpti & desorpti & meth & & & meth & & \\
\hline & od & on & on & od & & & od & & \\
\hline C-DS & 865.5 & 179.54 & 266.28 & 2.62 & 4.31 & 3.75 & 0.56 & 0.19 & 0.25 \\
\hline & 9 & & & & & & & & \\
\hline
\end{tabular}


Table 4. Textural properties according to the Dubinin-Radushkevich (D-R) model calculated from the $\mathrm{N}_{2}$ adsorption isotherms at $77.35 \mathrm{~K}$ for activated carbon.

\begin{tabular}{|c|c|c|c|c|c|}
\hline Sample & $\mathrm{W}_{0}\left(\mathrm{~cm}^{3} / \mathrm{g}\right)$ & $\mathrm{E}_{0}(\mathrm{~kJ} / \mathrm{mol})$ & $\mathrm{L}(\mathrm{nm})$ & $\mathrm{V}\left(\mathrm{cm}^{3} / \mathrm{g}\right)$ & $\mathrm{S}_{\mathrm{N} 2}\left(\mathrm{~m}^{2} / \mathrm{g}\right)$ \\
\hline AC-DS & 312.60 & 17.30 & 1.39 & 0.46 & 1295.20 \\
\hline
\end{tabular}

Table 5. Chemical characteristics of the activated carbon from date stones, AC-DS.

\begin{tabular}{|c|c|c|c|}
\hline Adsorbent & Acidity (meq g/g) & Basicity (meq g/g) & pHPZC \\
\hline AC-DS & 4.5 & 2.5 & 7.7 \\
\hline
\end{tabular}


Table 6. Isotherm constants for the adsorption of TIM from aqueous solutions onto AC-DS at different temperatures.

\begin{tabular}{|c|c|c|c|c|c|c|}
\hline \multicolumn{3}{|c|}{ Model } & \multicolumn{4}{|c|}{$\mathrm{T}\left({ }^{\circ} \mathrm{C}\right)$} \\
\hline \multirow{8}{*}{$\begin{array}{c}\text { Two } \\
\text { parameters }\end{array}$} & \multirow[t]{5}{*}{ Langmuir } & Parameters & 10 & 25 & 35 & 40 \\
\hline & & Qex(mg/g) & 42.23 & 50.62 & 56.41 & 60.52 \\
\hline & & $\mathrm{Q}_{\mathrm{m}}(\mathrm{mg} / \mathrm{g})$ & 45.44 & 49.92 & 56.42 & 57.37 \\
\hline & & $\mathrm{K}_{\mathrm{L}}(\mathrm{L} / \mathrm{mg})$ & 0.191 & 0.320 & 0.197 & 0.709 \\
\hline & & $\mathrm{R}^{2}$ & 0.983 & 0.962 & 0.988 & 0.953 \\
\hline & \multirow[t]{3}{*}{ Freundlich } & $1 / \mathrm{n}$ & 0.2500 & 0.2190 & 0.2538 & 0.1811 \\
\hline & & $\mathrm{K}_{\mathrm{F}}(\mathrm{mg} / \mathrm{g})(\mathrm{L} / \mathrm{mg})^{1 / \mathrm{n}}$ & 15.96 & 21.20 & 19.39 & 29.99 \\
\hline & & $\mathrm{R}^{2}$ & 0.949 & 0.978 & 0.971 & 0.978 \\
\hline \multirow{8}{*}{$\begin{array}{c}\text { Tree } \\
\text { parameters }\end{array}$} & \multirow[t]{4}{*}{ Sips } & $\mathrm{Q}_{\mathrm{m}}(\mathrm{mg} / \mathrm{g})$ & 50.25 & 69.98 & 67.31 & 78.39 \\
\hline & & $\mathrm{K}_{\mathrm{S}}(\mathrm{L} / \mathrm{mg})$ & 0.154 & 0.112 & 0.125 & 0.249 \\
\hline & & $\mathrm{m}$ & 0.76 & 0.50 & 0.70 & 0.45 \\
\hline & & $\mathrm{R}^{2}$ & 0.988 & 0.991 & 0.997 & 0.994 \\
\hline & \multirow{4}{*}{$\begin{array}{l}\text { Redlich } \\
\text { Peterson }\end{array}$} & $\mathrm{K}_{\mathrm{R}}$ & 10.85 & 44.02 & 17.56 & 124.13 \\
\hline & & $\mathrm{a}_{\mathrm{R}}$ & 0.30 & 1.58 & 0.50 & 3.41 \\
\hline & & $\mathrm{g}$ & 0.94 & 0.85 & 0.88 & 0.87 \\
\hline & & $\mathrm{R}^{2}$ & 0.987 & 0.987 & 0.998 & 0.989 \\
\hline
\end{tabular}


Table 7. Statistical Analysis of adsorption data.

\begin{tabular}{|c|c|c|c|c|c|}
\hline & \multirow[t]{3}{*}{$\mathrm{T}\left({ }^{\circ} \mathrm{C}\right)$} & \multicolumn{4}{|c|}{ Model } \\
\hline & & \multicolumn{2}{|c|}{ Two parameters } & \multicolumn{2}{|c|}{ Three parameters } \\
\hline & & Freundlich & Langmuir & Sips & Peterson \\
\hline \multirow[t]{5}{*}{ HYBRID } & 10 & 20.50 & 15.79 & 8.09 & 12.64 \\
\hline & 25 & 13.36 & 32.66 & 5.57 & 6.65 \\
\hline & 35 & 39.27 & 44.44 & 1.77 & 0.59 \\
\hline & 40 & 19.99 & 30.69 & 4.91 & 1.38 \\
\hline & Average & 23.28 & 30.90 & 5.09 & 5.32 \\
\hline \multirow[t]{5}{*}{ APE } & 10 & 0.73 & 1.50 & 0.31 & 0.75 \\
\hline & 25 & 0.31 & 1.47 & 0.08 & 0.02 \\
\hline & 35 & 2.34 & 1.07 & 0.43 & 0.27 \\
\hline & 40 & 0.14 & 1.82 & 0.02 & 0.03 \\
\hline & Average & 0.52 & 1.47 & 0.06 & 0.11 \\
\hline \multirow[t]{5}{*}{$\chi^{2}$} & 10 & 1.85 & 1.42 & 0.65 & 1.01 \\
\hline & 25 & 1.20 & 2.94 & 0.45 & 0.60 \\
\hline & 35 & 3.54 & 4.00 & 0.14 & 0.05 \\
\hline & 40 & 1.80 & 2.76 & 0.39 & 0.12 \\
\hline & Average & 2.10 & 2.78 & 0.41 & 0.45 \\
\hline
\end{tabular}


Table 8. Parameters from kinetic models for the adsorption of TIM $\left(\mathrm{T}=23{ }^{\circ} \mathrm{C}, \mathrm{pH}=8\right)$.

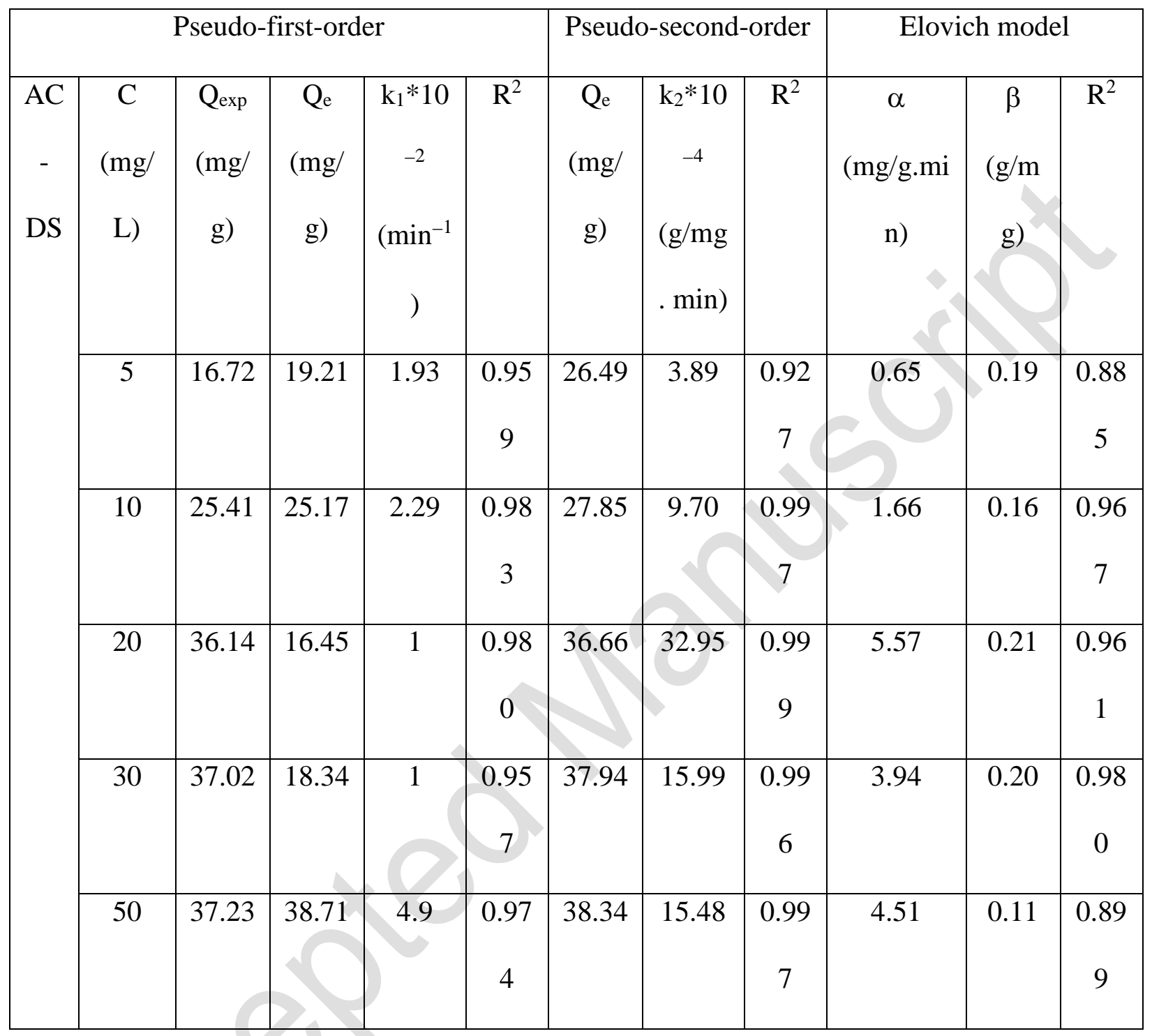


Table 9. Intraparticle diffusion model Parameters for the adsorption of TIM onto AC-DS adsorbent $\left(\mathrm{T}=23{ }^{\circ} \mathrm{C}, \mathrm{pH}=8\right)$.

\begin{tabular}{|c|c|c|c|c|c|c|}
\hline \multicolumn{7}{|c|}{ Intraparticle diffusion model } \\
\hline C(mg/g) & \multicolumn{3}{|c|}{ First step } & \multicolumn{3}{c|}{ Second step } \\
\cline { 2 - 7 } & kid & C & $\mathrm{R}^{2}$ & $\mathrm{k}_{\text {id }}$ & $\mathrm{C}$ & $\mathrm{R}^{2}$ \\
\hline 10 & 2.99 & 3.83 & 0.978 & 0.52 & 15.63 & 0.986 \\
\hline 20 & 1.95 & 16.28 & 0.977 & 0.25 & 31.28 & 0.89 \\
\hline 30 & 2.59 & 10.55 & 0.978 & 0.88 & 21.17 & 0.959 \\
\hline
\end{tabular}


Table 10. Thermodynamic parameters for the adsorption of TIM on AC-DS.

\begin{tabular}{|c|c|c|c|c|c|}
\hline $\mathrm{T}(\mathrm{K})$ & $\mathrm{K}_{\mathrm{c}}$ & $\Delta \mathrm{H}(\mathrm{KJ} / \mathrm{mol})$ & $\Delta \mathrm{S}(\mathrm{J} / \mathrm{mol} . \mathrm{K})$ & $\Delta \mathrm{G}(\mathrm{KJ} / \mathrm{mol} . \mathrm{K})$ & $\overline{\mathrm{R}^{2}}$ \\
\hline 283 & 0.52 & \multirow[t]{4}{*}{10.121} & \multirow[t]{4}{*}{87.82} & -14.73 & \multirow[t]{4}{*}{0.998} \\
\hline 298 & 0.66 & & & -16.40 & \\
\hline 308 & 0.74 & & & -16.92 & \\
\hline 313 & 0.79 & & & -17.37 & \\
\hline
\end{tabular}


Figure 1. Tiemoniummethylsulfate chemical structure. (3-(4-methylmorpholin-4-ium-4-yl)-1phenyl-1-thiophen-2-ylpropan-1-ol; methyl sulfate).

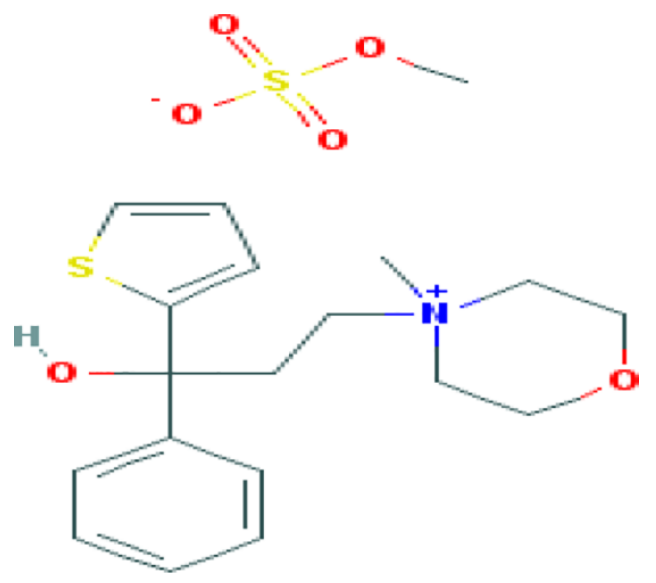


Figure 2. Nitrogen adsorption-desorption isotherms of AC-DS at $77.35^{\circ} \mathrm{C}$.

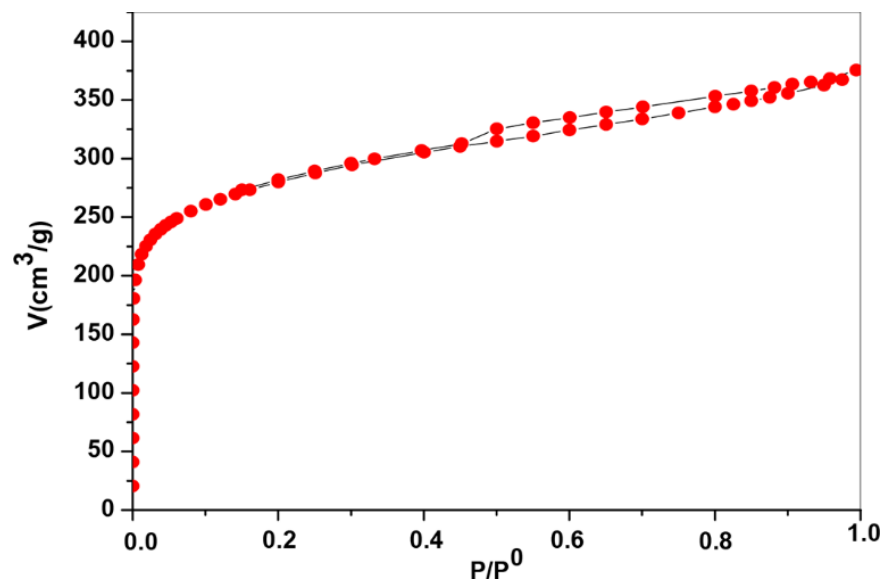


Figure 3. The change in final $\mathrm{pH}$ as a function of the initial $\mathrm{pH}$ for solutions of AC-DS during the determination of the point of zero charge PZC.

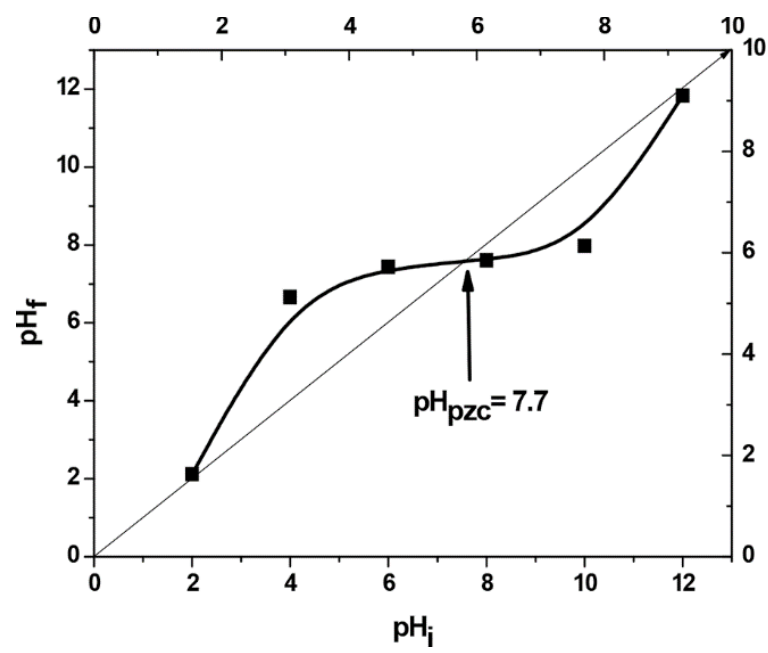


Figure 4. FTIR spectra of AC-DS cones before and after adsorption in the range $4000-500 \mathrm{~cm}^{-1}$.

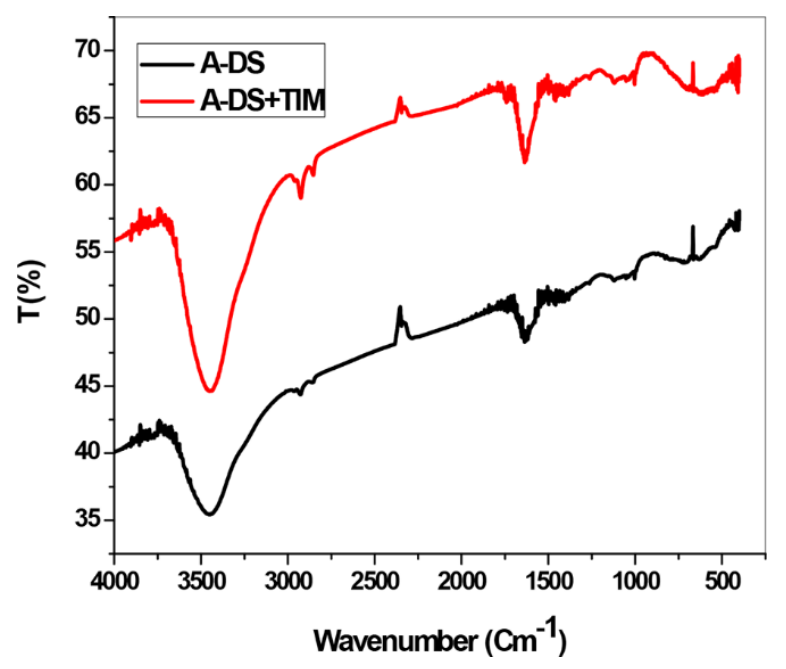


Figure 5.
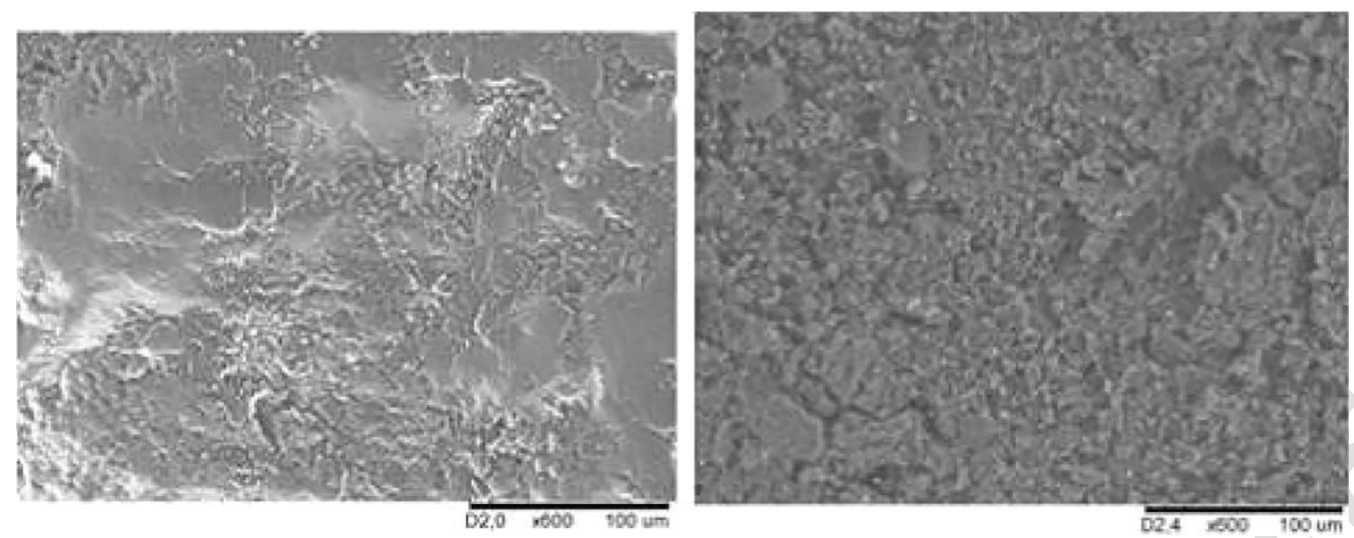

$02.4 \times 000 \quad 100 \mathrm{um}$ 
Figure 6. Effect of $\mathrm{pH}$ on the adsorption capacity of $\mathrm{TIM}\left(\mathrm{T}=25^{\circ} \mathrm{C}\right.$, agitation speed $\left.=250 \mathrm{rpm}\right)$.

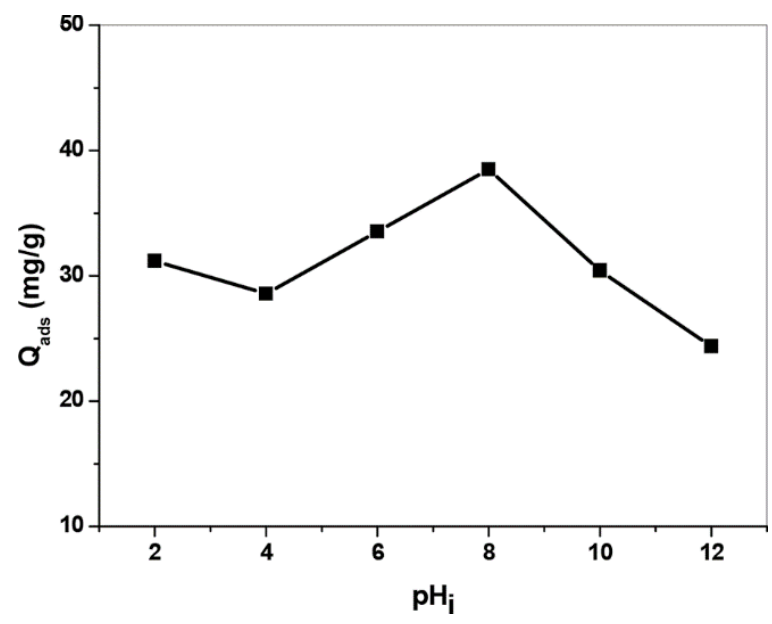


Figure 7. Effect of the contact time and the initial TIM concentration on the adsorption capacity of A-DS $\left(\mathrm{T}=25^{\circ} \mathrm{C}\right.$, agitation speed $\left.=250 \mathrm{rpm}, \mathrm{pH}=8\right)$.

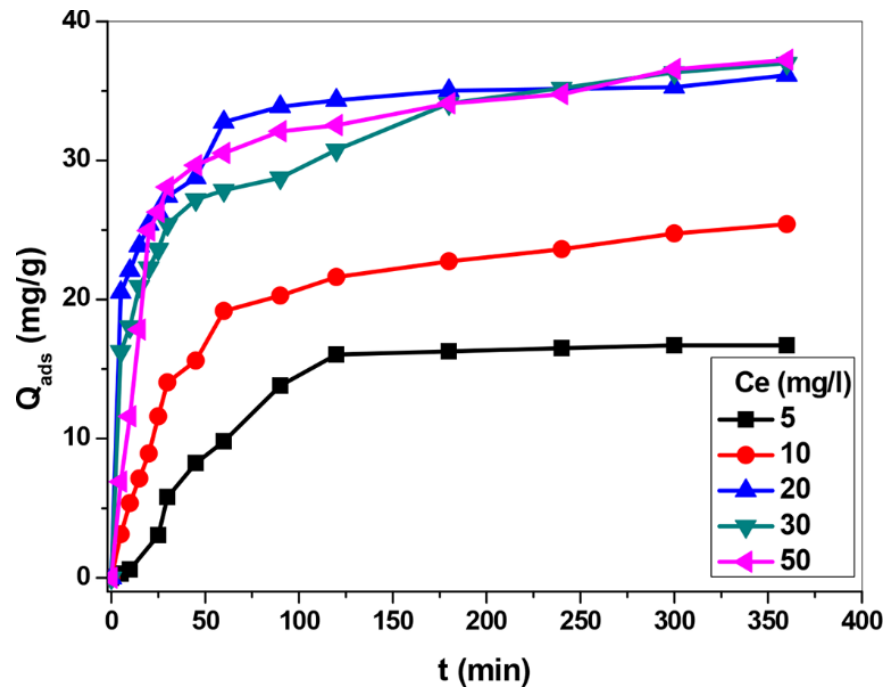


Figure 8. Equilibrium isotherms for TIM onto AC-DS adsorbent at different temperatures. Comparison between experimental data (symbols) and predictions of the Langmuir (continuous line) and Freundlich (a) (dash line), and Sips (continuous lines) and P-R models (dash lines) (b) (agitation speed $=250 \mathrm{rpm}, \mathrm{pH}=8$ ).
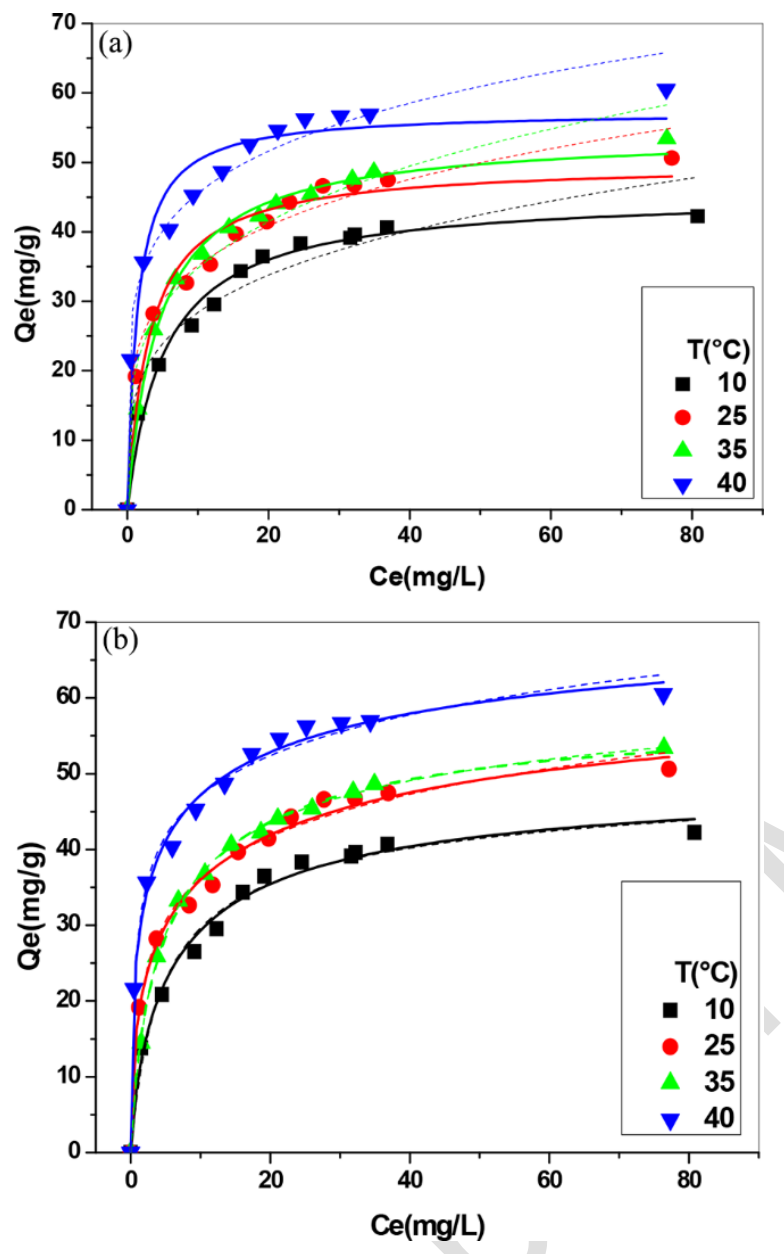
Figure 9. Experimental (symbols) and calculated data (continuous lines) by means of pseudofirst-order (a) and pseudo-second order kinetic models (b) for TIM adsorption onto AC-DS adsorbent at various concentrations. $\left(\mathrm{T}=25^{\circ} \mathrm{C}\right.$ agitation speed $\left.=250 \mathrm{rpm}, \mathrm{pH}=8\right)$.
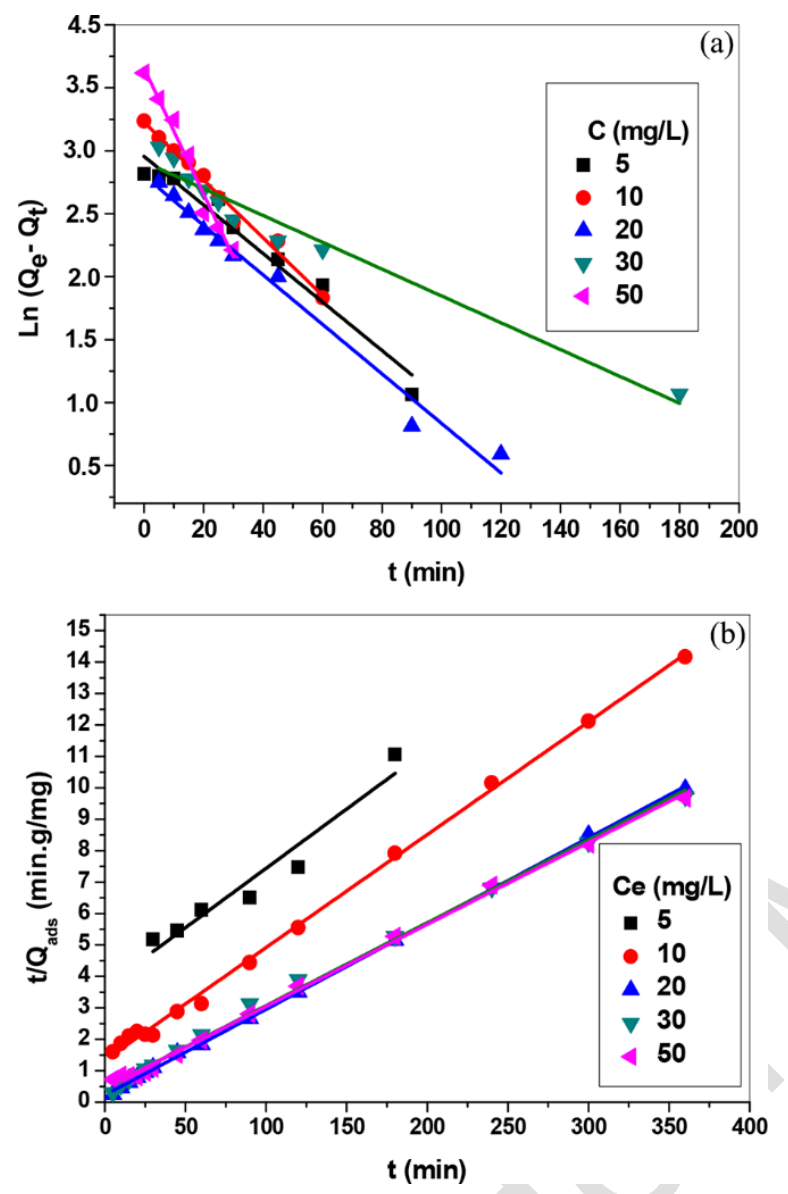
Figure 10. Experimental (symbols) and calculated data (continuous lines) by means of Elovich kinetic model for TIM adsorption onto AC-DS adsorbent at various concentrations. $\left(\mathrm{T}=25^{\circ} \mathrm{C}\right.$ agitation speed $=250 \mathrm{rpm}, \mathrm{pH}=8$ ).

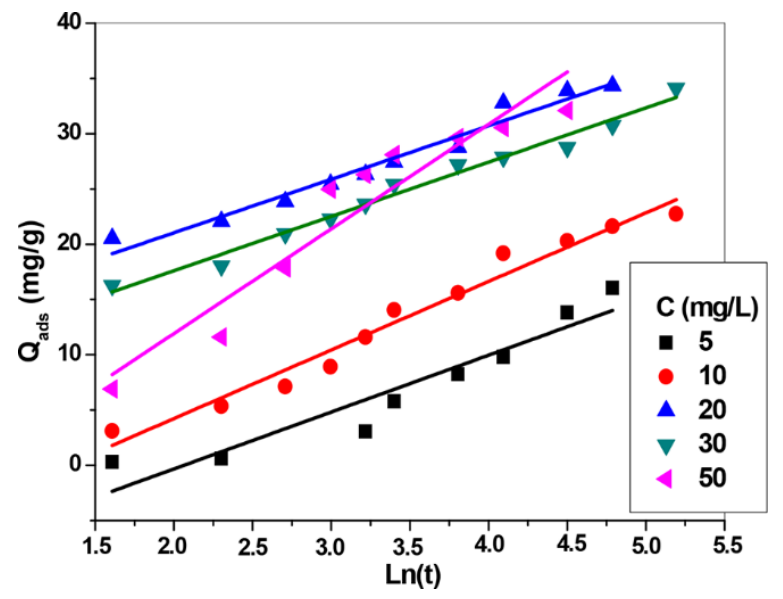


Figure 11. Experimental (symbols) and calculated data (continuous lines) by means of Intraparticle diffusion kinetic model for TIM adsorption onto AC-DS adsorbent at various concentrations. $\left(\mathrm{T}=25^{\circ} \mathrm{C}\right.$ agitation speed $\left.=250 \mathrm{rpm}, \mathrm{pH}=8\right)$.

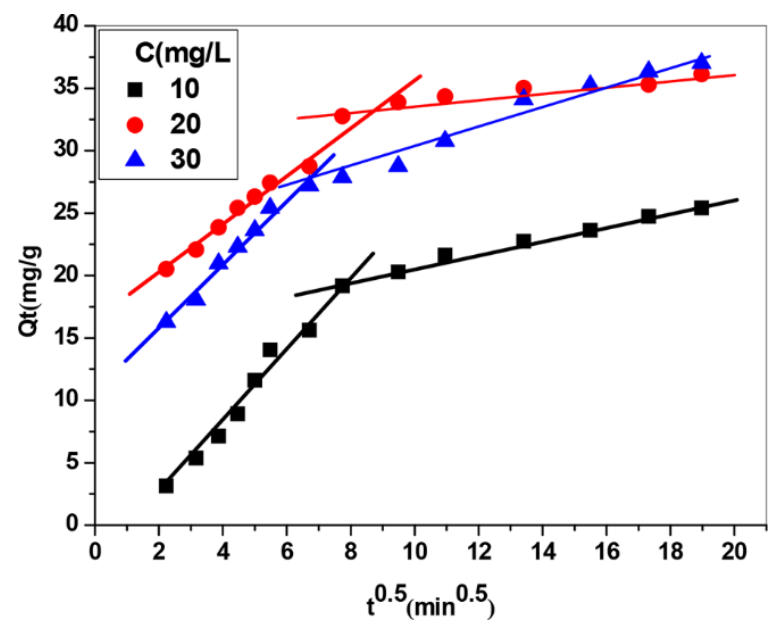

